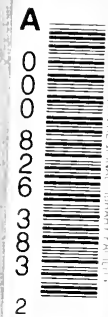


, 


\title{
Columbia University.
}

\author{
Department of Geology
}

\section{Syllabus of Historical Geology}

BY

Professor A. W. GRABAU

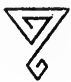

NEW YORK :

A. G. SEILER, PUBlisheR 
QE
41
$C 7$ 


\title{
COLUMBIA UNIVERSITY
}

\author{
DEPARTMENT OF GEOLOGY
}

\section{Syllabus of Historical Geology}

BY

Professor A. W. GRABAU

Definition: Historical Geology treats of the history of the earth and its inhabitants from the beginning to the present time.

Three Aspects: I Stratigraphy: History of Rocky frame work-chiefly of the stratified rocks or Strata. II Palaeontology: History of life of the earth. III Physiography: History of development of surface features.

1 STRATIGRAPHY: Represented by maps and sections. Sections are:

1 Natural or cross-sections giving succession and structure.

2 Columnar Sections-giving succession and thickness of rocks only.

3 Ideal sections-restoring former conditions. 


\section{TABLE OF GEOLOGIC FORMATIONS.}

Psychozoic or Quaternary.

Holocenic or recent

Pleistocenic

Cenozoic or Tertiary.

Pliocenic

Miocenic

Oligocenic

Eocenic

Mesozoic or Secondary.

Cretacic

Comanchic

Jurassic

Triassic

Palaeozoic or Transition.

Permic

Carbonic (Pennsylvanic)

Mississippic

Devonic

Siluric

Ordovicic

Cambric

Eozoic (Proterozoic) or Primary in Part.

Algonkic or Huronic

Azoic (Archaeozoic) or Primary.

Archaeic 
GEOLOGICAL HORIZON. A given level in the geological column-recognizable by fossils or otherwise at different localities. A certain moment in the geological history of the earth.

ERA, PERIOD, EPOCH, AGE. Successive divisions of geologic time.

DIVISION, SYSTEM, SERIES, STAGE. Corresponding divisions of the geological column.

FORMATION. The geological unit-character. ized by similarity of lithological features and organic remains. Formations are named from the locality where best developed and first studied then becomes the type locality.

GROUP. A division of the geological column of variable value comprising two or more formations, according as used-Hamilton group, Monroe group, etc.

STRATUM. A single lithological unit. A layer or bed-bedded formations are stratified.

\section{SUPERPOSITION OF STRATA OR FORMA-} TIONS. The original order of succession in which the strata or formations were deposited.

CORRELATION. The identification of strata or formations of equal age, i.e., formed at the same time, over wide areas, by various means, such as superposition, lithologic and stratigraphic continuity, organic contents, etc.

II. PALAEONTOLOGY. The Study of Fossils. "Fossils are the remains of animals or plants, or the direct record of their presence, preserved in the rocks of the earth's crust from the earliest to the present time." 
INDEX FOSSILS. Characteristic fossils by which a given geological horizon may be recognized at different localities.

\section{LABORATORY WORK WITH RECENT AND FOSSIL PLANTS.}

Trays A. $1-10$.

I. PROTOPHYTA. The simplest unicellular plants of low organization. They include the Bacteria, which are known from the Palaeozoic on, often placed under the Algae.

II. THALLOPHYTA. Comprise plants of low order consisting of a "thallus" which shows no differentiation into stem, leaf or root. They include-

1. Algae,

2. Fungi,

3. Lichens.

1. ALGAE, or sea weeds are divisible into three groups, according to their coloring matter, viz: (a) Green algae, (b) Brown algae, and (c) Red algae.

(The Bacteria, etc., are often included as a separate group - the Blue-green algae.)

(a ) Green Algae-Represented by modern sea lettuce (Ulva) a thin bright green leaf-like thallus, common on seashore. Many forms secrete lime as Halimeda which is common on coral reefs - and Chara (1 a) the common stone-wort found in fresh water pools and lakes; it makes fresh water marl and limestore. The spore fruit is globular or ovoid with spiral ridges and is often found fossil.

(b) Brown Algae-Often of large size, as the common Devil's Apron, or Laminaria (1c) which 
grows 3 or 4 metres in length with a stout stalk ending in a branching rootlike manner, grasping stones or shells. The blade, stalk and "root" commonly covered with great variety of organisms. Giant kelp of the Pacific (Macrocystis) said sometimes to reach a length of three hundred meters. The common rock weed, Fucus vesiculosus (1d) covers rocks between tide. Furnished with air bladders; usually has many animals (bryozoa, hydroids, etc.) attached. The Gulf weed Sargassum is closely related. Found south from Cape Cod, fioats in Sargassum sea. Many animals live on it.

The Diatoms (1e) are miscroscopic brown algae secreting a siliceous skeleton which is preserved. Habitat planktonic in open sea or benthonic on other seaweeds; also in fresh water. Capable of motion. Skeleton a highly ornate transparent "frustule" - of two parts "box and lid" like; forms diatomaceous earth (1) often of great thickness as under Richmond, Va.

(c) Red Algae - of many shades, mostly marine. Chondrus crispus or Irish moss is collected as food. Many microscopic. Several secrete lime, i.e., the Coralline seaweed or Nullipore. Corallina, a branching brittle form, Lithothamnion ( $2 /$ forms pink encrustations on stones, smooth or knobby. Becomes white when dry. Important on coral reefs.

Fucoids (3) a name applied to impressions on rock believed to be of fossil seaweeds.

2. FUNGI, low terrestrial plants, destitute of chlorophyl or leaf-green, depend for food on organic matter either living (parasitic) or dead (saprophytic). They include the rusts, mildews, smuts, etc., and the toadstools, mushrooms and shelf fungi (Polyporous, Daedalia, etc.) (4) commonly growing on trees. 
3. LICHENS-Terrestrial plants formed of fungi growing in intimate (symbiotic) association with various forms of algae. Cover stones, tree trunks, fences etc., as a grayish curly crust, often with reddish-brown cup-like spore fruits (Parmelia) (5), or hang in tufts from branches of trees in swamps, etc., like the long gray Usnea (5a).

III. BRYOPHYTA. Mosses. These are for the most part land plants, growing in woods and swamps, with stems and leaves and fruit spores. They include the Liverworts like the scale moss (Madotheca), the true mosses (musci) which in. clude the Peat mosses, Hypnum and Sphagnum. (6), the hairy cap moss (Polytrichum) (6a), the pine tree moss (Clemacium) ( $6 \mathrm{~b})$ and many others. Mosses are rare as fossils.

IV. PTERIDOPHYTA or Fern plants. The high. est of the flowerless plants or Cryptogams. They include (1) the horse tails or Equisetales, (2) the Club mosses or Lycopodales, (3) the extinct Sphenophyllales, and (4) the Ferns or Filicales.

1. Equisetales or horse tails-represented by the living genus, Equisetum (6c) growing in low moist ground, and along railroad embankments. It has a creeping root stock of a meter or more in length, and two kinds of branches - a coarse one, bearing a spore cone, and a slender sterile one with many branches, both are jointed and hollow. Plant rough and gritty, due to presence of flint particles. Fossil representatives of this group are the Cala. mites (6d) which grew to the size of trees in Carbonic time from 30 to 60 meters high. They had a thicker wall, and were generally preserved as stony casts. 
2. Lycopods, or Club mosses include the ground pine Lycopodium (6e) of our woods, bearing leaves and numerous spores (Lycopodium powder) and the extinct tree-like Sigillaria (6f) with their trunks marked by leaf scars in vertical rows and Lepidodendron $(6 \mathrm{~g})$ with the scars in spirals. The creeping root of these is called Stigmaria $(6 \mathrm{~h})$ and bore many rootlets.

3. Sphenophyllum (6i) consists of long slender stems with whorls of leafs. Entirely extinct.

7. Ferns-include (a) the common forms (6j) which are represented by numerous genera and species, mostly low-some forming low trees (in tropics). The frond consists of a stipe or leaf stalk arising from an underground stem or rhizome and the blade, often divided into many pinnules. Fruit in form of spores, often on under. side of frond. (b) The Water ferns or Rhizocarps (6k) which live in water, often floating, spores of such types (Protosalvinia) (6 1) occur in quantities in black shales of Ohio, etc., and are believed to be source of petroleum. (c) Palaeozoic forms and cycad ferns (7) many of them of a higher order than living ferns and related to the Spermaphytes.

V. SPERMAPHYTA or seed plants. These include Gymnosperms or naked seeded plants, and the Angiosperms, or covered seed plants.

A. The Gymnosperms include conifers, cycads, joint firs, and the extinct Cordaites (8) with strap. shaped leaves. Cycads are palm-like plants common in the Mesozoic. Conifers begin in the late Palaeozoic and are represented to-day by the yews (Taxus), the Japanese gingko, the pines, spruce, fir, hemlock, tamarack, cypress, arbor vitae, etc. 
B. The Angiosperms include the remaining flowering plants and are divided into:

1. Monocotyledons, or endogenous plants in. cluding the lilies, palms, the grasses (including the cereals) banana, ginger, etc., orchids, the water plantain and arrow head and others-pondweed (including the eel grass, Zostera ( $8 d)$, the cat tail, etc. They have mostly parallel veined leaves and flowers in parts of threes. Their growth is from within. They first appear in the early Mesozoic.

2. Dicotyledons, or exogenous plants, which include the largest number of plants such as the butter cup, rose, pink, etc., with separate petals, (Choripetalae or Polypetalae), the honeysuckle, huckleberry, lilac, etc., with petals more or less united (Gamopetalae) and the Buckwheat, sorrel, pepper, mistletoe, nettle, etc., without petals (Apetalae). Under these groups are also included the common deciduous trees (oak, maple, tulip, willow, etc.). Dicotyledons first appeared in the Cretacic. (8f).

\section{LABORATORY WORK WITH RECENT AND FOSSIL ANIMALS.}

Trays A. 1 -10 - continued.

\section{PROTOZOA.}

1. Foraminifera: Globigerina (9a), one of the common forms leading pelagic (planktonic) life in open ocean. Shells accumulate as Globigerina ooze on ocean bottom. Note successively added cham. bers and foramina or pores. Orbiculina (9) a shallow water form, abounds in sand of coral islands in tropics. Note successive addition of linear cham. bers, also spreading of form. 
Nummulites (10) A fossil foraminiferon abounding in Eocenic seas. Note numerous chambers enclosing one another.

Chalk (11) is largely composed of microscopic foraminifera besides other calcareous organisms. In the slide (11a) note Textularia one of the common types, with cells arranged biserially, and Rotalia with cells arranged in spiral (Cretacic age).

2. Radiolaria-Protozoa of pelagic (planktonic) habitat. The highly ornate siliceous or glass shells are internal and accumulate in deeper part of sea forming radiolarian ooze. Barbadoes earth (12a), fossil radiolarian ooze from Barbadoes; radiolarite ( $12 \mathrm{~b}$ ) a fiinty or cherty rock composed largely of the shells of radiolaria.

\section{PORIFERA:}

Sponges-Main mass of dried specimens (13) consists of net-work of horny fibres-the supporting structure from which flesh has been removed. It encloses one or more cylindrical spaces, each opening above in an osculum. Water passing through body mass, ejected again from osculum. In many sponges siliceous spicules (13a) more or less replace the horny fibres. In many fossil sponges (13b) fibres are all siliceous. Some sponges tunnel into shells or rocks to which they grow (Boring sponge, Clione sulphurea-14).

\section{COELENTERATA:}

1. Hydrozoa (Hydroids) mostly marine, generally colonial, attached to rocks or sea weeds. Body covered by delicate horny sheath either furnished with numerous bell-shaped hydrothecae or cups, each on a stem and enclosing a polyp, (Campanularia, 15a) or with a double row of close set hydro. thecae (Sertularia, 15b). When dried the sheath 
alone remains, a horny substance, suggestive of delicate seaweeds (15).

Dictyonema (17) - a fossil form (Graptolite) represents the sheath compressed on shale into carbonaceous film - the several strands connected by cross-threads into a net work. The cups seldom visible.

2. Hydrocoralline: A group in which the sheath is replaced by a calcareous structure resembling coral. Millepora (16). The cups open by pores on the surface of the structure-there being two sets of different sizes-the larger (gastropores) lodging the feeding polyps, the smaller (dactylopores) the fighting polyps. In section note that the tubes (the representative of the cups) are successively divided off by floors or tabulae. Com. mon on coral reefs. Fossil representatives of this group are known as Stromatopora (18) in which the calcareous material is deposited in successive layers. An important reef builder of Palaeozoic time. Sometimes formed masses $10 \mathrm{ft}$. in diameter.

3. Actinozoa (Corals). The skeletal structure (corallum) of calcium carbonate or lime alone remains-see illustrations in Saville-Kent, Great Barrier Reef, for aspect and color of polyps.

Eusmylia (19) a simple recent coral. Note radiating plates or septa and wall-increase by division of older individuals.

Streptelasma (20) a simple fossil coral show. ing wall and septa-interspaces filled with mud hardened into rock.

Madrepora (21) (Stag-horn coral). A recent compound branching coral with small individuals separated by solid calcareous tissue. Septa rudi. mentary. A common reef builder of to-day. 
Astræa (22) (Star coral) compound "head," consisting of closely arranged individuals, each showing septa wall, etc. A modern reef builder.

Acervularia (23) fossil Astraean coral showing septa and wall in each individual. Interspaces all filled by lime mud, hardened to rock, hence polishing was possible. A Palæozoic reef builder-often of great size.

\section{Trays A. 11.20.}

\section{MOLLUSCOIDEA}

\section{BRYOZOA:}

Minute colonial organisms chiefly marine, encrusting sea weed stalks, etc. Membranipora (1) consists of numerous small calcareous cells, each one lodging an animal (zooid). Monticulipora (2) a fossil Bryozoan of the Palaeozoic. The cells are deep, closely crowded and divided off into tiers by tabulae.

\section{BRACHIOPODA:}

Shell of two valves, dorsal and ventral-the valves nearly equal as in Lingula (3a) and attached by long fleshy stem or pedicle; or more generally unequal in size as in Terebratula (3). Each valve is symmetrical with reference to median line. Larger valve with round foramen through which fleshy pedicle projects as shown in recent Terebratula ( $3 b)$.

Strophomena (4) one valve concave leaving very narrow space for soft parts of animal. Hinge elongated, with flattened hinge area. Symmetry as in Terebratula.

\section{MOLLUSCA}

1. PELECYPODA: (Bivalve Mollusks).

Shell of two valves-right and left. Generally equal in size and form as in Venus (5) or Cardita 
(6) or slightly unequal but with the valves nearly symmetrical as in the scallops or Pecten (7). Increase of shell by addition of layers around initial point or beak. Surface smooth but marked by growth lines (5) or with radiating plications ( 6 and 7 ). Form nearly circular as in Cardita (6) or elongate as in Mytilus (8). Interior of valve showing muscle scars, etc. (5). Fossil forms often very similar to recent ones as in Modiola (9).

\section{GASTROPODA (Snails).}

Spirally coiled shells either low spired as in the garden snail Helix (10) or the sea snail Nerita (11) or elongate spired as in Turritella recent (13) or fossil (14). Aperture round with reflexed lip as in Helix (10) with sharp lip (11) with spinous lip as in Murex (11a) or with lip notched at back and often drawn out into a canal as in Fusus or Purpura (12). The shell is sometimes cup-shaped, as in the Limpet, and this has sometimes an apical hole as in the keyhole Limpet Fissurella (15).

\section{PTEROPODA (Sea Butterflies).}

Shells small, generally more or less transparent, of variable form. The simplest a small, slender, tapering tube (Styliola) (16a) living near the surface of the ocean as plankton, the dead shells ac. cumulating as Pteropod ooze on the ocean floor. Styliolina (16) a fossil form compressed on shale makes up limestone in the Devonic, estimated to contain 40,000 individuals to the cubic inch. (17).

\section{CEPHALOPODA.}

To this class belong the living cuttle fish, Squid, Devil fish, Nautilus, and a host of fossil forms. Nautilns (18a) builds a shell coiled in a single 
plane and divided by septa which are pierced by the siphuncle. Orthoceras (18) is like Nautilus straightened out. When the shell is removed, as is usually the case, the edges of the septa are seen and the space between filled with hardened mud. Note position of siphuncle (not always clearly shown). Specimens showing shell partly preserved are rare $(18 b)$.

Ammonites (19) are fossil forms with shells often ornamented and with the edges of the septa highly fluted and complexly folded. They are all extinct. Ceratites and Goniatites are early forms.

Spirula (19a) is a modern coiled shell entirely within the animal. It shows the septa and siphuncle.

Belemnites. A fossil form with the shell or phragmocone (20a) enclosed in a calcareous guard (20) which is commonly cigar-shaped and has a conical depression for the reception of the shell at one end.

\section{VERMES-WORMS.}

Marine, fresh-water and terrestrial animals mostly without hard parts capable of preservation. One order builds tubes either of cementer sand grains or of lime. Serpula (21) is an irregular tube attached to shells or occurring in clusters. Spirula is a spirally coiled tube found in deeper water, both recent (22) and fossil (23) attached to seaweed, shells or other objects of support. Worm tubes in sand of sea shore are U-shaped. two sides separately preserved, as in Scolithus (23a). Worm castings often preserved in rocks resulting from hardening of old mud flats ( $23 \mathrm{~b})$. Internal jaws (Conodonts) also preserved (23c). 


\section{ARTHROPODA}

A. Crustacea.

1. Malacostraca: The highest order represent. ed by Decapoda, (ten-footed crustacea) which comprise lobsters and crayfish (Macrura) (24a) with elongate cephalothoracic shield and long ringed abdomen; 5 pair of walking legs of which one is generally modified into a grasping claw (chela); with antennae, stalked eyes, mouth parts, etc., and Crabs (Brachyura) (24b) with broad, more or less flattened carapace, five pair of walking legs, one clawed, abdomen tail-like, commonly turned under. Fossil Decapods are often found represented by claws only in Mesozoic and Cenozoic strata (24), also whole carapaces.

2. Cirripedia: include the barnacles, degenerate crustacea attached to rock, etc., acorn barnacle (Balanus) (25) or by fleshy stem to logs, etc.; goose barnacle (Lepas) (26). Both types found fossil.

3. Ostracoda are minute bivalve crustacea often making up masses of rock, either marine (Leperditia, etc.) (26a) or fresh water (Cypris, etc.) $(26 \mathrm{~b})$.

4. The order Trilobita is the most important extinct order, entirely confined to the Palaeozoic (27) composed of head, thorax and pygidiumeach showing central axis and sides. Eyes often well developed, compound legs and antennae rarely preserved. Head often with separate "free cheeks." Thorax jointed, often permitting enroll. ment.

B. Acerata

5. Merostomes are highly developed Arthro. pods. Crustacea like. Body sometimes encased in 
solid carapace with only telson movable as in the modern horse-shoe crab or Limulus (27a) or with the thorax and abdomen both ringed and not separable as in Eurypterus (27b), a Palaeozoic form.

\section{ECHINODERIMATA. ("Spiny Skinned")} Marine organisms-one group represented by the star fish, a common recent form (28) and also found fossil (28a). The Brittle star (28b) also found fossil. A second group comprise sea urchins having a calcareous "test" made of spine-bearing plates; abundant in modern seas (Strongylocentrotus drobachiensis) (29) and fossil chiefly in the Mesozoic and later. The form is regular with central mouth as in Cidaris (30) and with large spines (31); or irregular; of elongate form with mouth at one end, as in Maretia (32). The third class comprises the crinoids which are represented by recent forms in tropical seas (33a) and by fossil forms (35). They consist of a calyx (35) bearing arms (33) and generally attached by a stem or stalk (34). Two other types belong here, both extinct, the Blastoid (Pentremites) (36) with regular bud-like form, and the Cystoid (37) composed of irregular plates. Both were attached by stems and had rudimentary or no arms.

\section{VERTERBRATA.}

These have internal skeletons generally capable of preservation, and often external limy or calcareous armors. Dermal spines, teeth, etc., are also cabable of preservation. Include: Fish, Amphibians, Reptiles, Birds and Mammals.

\section{STRATIGRAPHIC MAPS AND SECTIONS.}

\section{THE PRE CAMBRIC.}

Foundation complex of crystalline rarely un. metamorphosed rocks, generally divisible into 
Archaean and Algonkian or Huronian. Underlies all later formations.

Distribution: North America. Canadian shield and Newfoundland, Wisconsin-Michigan area, Adirondack area and Southern Appalachians: original centers of deposition. New EnglandHudson area; Rocky Mountains area and small patches in Texas, Missouri and the Cordilleran area mostly brought up by subsequent folding or faulting.

Europe. Northwest Scotland and Highland area in part and Ireland-Fenno-Scandia, Central France. Main centers of deposition of early Palaeozoic strata. Patches in Alps, Bohemia, etc., brought up by subsequent disturbance and erosion.

Origin: Archaean granites, gneisses, schists, etc. metamorphic mainly from ancient volcanic and other igneous rocks-some ancient sediments. Algonkian or Huronian-largely sediments, but mostly formed by rivers on land; fossils are seldom well preserved. Much metamorphism.

Contents: Much of metallic mineral deposit of world in the Pre Cambric. Not all metamorphic nor all mineral bearing deposits are Pre Cambric - some very recent.

\section{THE CAMBRIC.}

(Laboratory Trays B. 1-10.)

Named by Sedgwick from Cambria-ancient name of North Wales.

Two-fold division over earths' surface-Atlantic type, Pacific type. In each a threefold division recognizable, lower, middle and upper.

Greatest development in America.

Lower. In Atlantic province called Etcheminian from Indian tribe. Zone fossil Holmia. 
Pacific-called Georgian from Georgia Vermont. Zone fossil Olenellus.

Middle. In Atlantic called Acadian from Eastern Canada. Zone fossil Paradoxides. Pacific (not named). Zone fossil Olenoides.

Upper. Atlantic or Bretonian (from Cape Breton Island) Zone fossils: Olenus Microdiscus, (13) Pacific or Saratogan (from Saratoga, N. Y.) (Potsdamian) Zone fossils Dikellocephalus (14b) Lingulepis (14c).

Transition zone to Ordovicic. (Tremadoc division) contains Dictyonema( 15$)$.

Distribution and character: Atlantic province: Eastern New Foundland, New Brunswick and Cape Breton, etc.,-Eastern Massachusetts, England, Baltic region, Mediterranean region and Bohemia, the most famous section. Barrande placed all older fossiliferons rocks of Bohemia in the Silurian System and divided it into rocks with primordial or first fauna,- - second and third fauna. The first fauna is the Cambric (middle). Pacific province: Cordilleran region to Rocky Mountains, Texas, and extending northeast where now are Appalachiansthrough Pennsylvania, New Jersey, Eastern New York and Western Massachusetts, Vermont, Quebec to Western Newfoundland to Arctic Sea which covered north Scotland, China, Siberia, etc., also in India and Australia. Changes and rearrangements of shore lines in these periods are pronounced.

Material. In Pacific province basal sands passing up into limestones; shales rarer. In Atlantic muds and some limestones - the latter thickest in Mediterranean region. 


\title{
CHARACTERISTIC COLUMNAR SECTIONS
}

1 PACIFIC REGION: Nevada: Mostly limestones L. $4500 \mathrm{ft}$. M. $2600 \mathrm{ft}$. U. $1000 \mathrm{ft}$. Montana: L. absent, M. shales and limestones $1200 \mathrm{ft}$. U. absent by erosion. Colorado: (Rocky Mt. front range, L. \& M. absent U. Sandstone $100 \mathrm{ft}$. or more. Progressive overlap from west to east.

2. CENTRAL NORTH AMERICA: Southern Appalachians: Mostly limestones, L. $7000 \mathrm{ft}$. or more, M. $2000 \mathrm{ft}$. U. $3500 \mathrm{ft}$. Missouri: limestones, L. absent M. 200. ft. U. $100 \mathrm{ft}$. partial reduction of thickness by erosion. Minnesota. L. \& M. absent, $\mathrm{U}$. sandstone, $500 \mathrm{ft}$. partial reduction of thickness by erosion. Potsdam: special name for upper Cambric.

\section{LABORATORY WORK WITH FOSSILS.}

\author{
(Trays B. 1.10.)
}

\section{PRESERVATION.}

A. Actual record of entombment.

I. Original substance preserved. Soft parts as insect in amber (1a). Mammoth in ice. Original hard parts - shark's tooth (1), bones, shells.

II. Substance altered (a) by carbonization, as in Dictyonema (15), (b) by replacement with sil. ica as in silicified shells (2) or silicified wood (3).

III. Original substance destroyed. Impression or mold alone remains. Illustrated by artificial mold of pelecypod (Arca), both internal and ex. ternal (4) and natural mold of pelecypod (5) arti. ficial internal mold of Helix (6); natural internal mold of Turritella (7). 
B. Impressions left in transit. Foot prints (7a), trails (7b) of organisms, as in Arthrophycus (7c).

C. Artificial structures. Structures built by organisms from foreign substances, e.g., worm tubes as in Scolithus (10).

D. Coprolites or excrements of characteristic form, e.g., those of Jurassic Reptiles (7d).

\section{DISTORTION OF FOSSILS.}

By pressure, during folding or other tectonic movements fossils are of ten distorted so as to lose their original form. Flattening from settling of sediments is a common mode of distortion.

(8).

\section{PSEUDOFOSSILS.}

Delicate films of oxide of iron or manganese often simulate ferns or other fossil impressions; these are the dendrites (9).

\section{CAMBRIC FOSSILS.}

\section{(Trays B. 1-10-continued.)}

Dictyonema (15). Note fan-like branching and cross-threads, cups or thecae generally not shown. (See diagram). Cambro-Ordovicic transition zone.

Scolithus (10). Note smooth pencil-like filling of old tubes. Walls of tubes are agglutinated. Potsdamian.

Olenellus (12a). Besides form, note long pygidial spine; absence of suture, which would cut off free cheeks; outline of central part of head or glabella. Georgian. 
Paradoxides (12). Note broadening glabella; separation of free checks. (Acadian).

Microdiscus (13). Minute head and pygidial shields. No eyes. (Bretonian).

Olenus (14). Rather square glabella. (Bret. onian).

Dikellocephalus (14a). Large size; form; note spines on pygidium. (Potsdamian).

\section{THE ORDOVICIC SYSTEM}

(Laboratıry Trays B. 11-20.)

Named by Lapworth from ancient inhabitants of Western England. Originally called by Murchison Lower Silurian and by Sedgwick Upper Cam. brian. Two main types of sedimentation known: the sandstone-limestone type around the Canadian shield and in the Baltic and Mediterranean areas, and the sandy shale and shale type with graptolites, found more especially in marginal regions of the continents. A third type consists of river and wind laid sediments, formed in eastern United States and some other regions, and which are partly of a red color suggesting arid condi. tions.

Standard Series:

Fossils :

Upper or Trentonian.

Richmond formation. . Rhynchotrema (14) Lorraine ..........Platystrophia (13) Eden-(Frankfort) . .

Utica .......... Diplograptus (10) Triarthrus

Trenton, Prasopora (5) Dalmanella Plectambonites (16). Orthoceras (6) Asaphus (7). Trinucleus (8). 
Middle or Chazyan.

Black River ........Columnaria (4)

Lowville ..........Phytopsis (3)

Chazy .......... Maclurea (2)

Lower or Beekmantownian.

Beekmantown forma.

tion .......... Ophileta

\section{CHARACTERISTIC NATURAL SECTIONS.}

1. Lake Champlain section. Strata dip gently east; rest on crystallines of Adirondacks. Potsdam s. s. $1150 \mathrm{ft}$. followed by Beekmantown, $1800 \mathrm{ft}$.; Chazy, partly concealed under lake but forming islands-900 ft.; Black River $80 \mathrm{ft}$.; Trenton 300 ft.; Utica $600 \mathrm{ft}$; cut off by thrust fault on east bringing up Cambric.

2. Mohawk Valley section. Strata dip gently south. Adirondack crystallines; followed directly by lower Beekmantown $350 \mathrm{ft}$. forming cliffs; hiatus; Lowville (Upper Chazy) $30 \mathrm{ft}$.; Black River $10 \mathrm{ft}$.; Trenton limestone (at Trenton Falls) 250 ft.; Utica shale at Utica on Mohawk $600 \mathrm{ft}$. ; Frankfort shale $100 \mathrm{ft}$; hiatus; Oneida conglomerate forming cliffs $40 \mathrm{ft}$.; (Siluric).

3. Western New York section. Dipping gently south. Crystallines of Canada. Black River limestone $20 \mathrm{ft}$. Trenton l!mestone $900 \mathrm{ft}$. Utica -Lorraine $600 \mathrm{ft}$. mostly under Lake OntarioOswego sandstone $75 \mathrm{ft}$. (deepest part of lake). Queenston red shale and sandstone (Richmond) $1100 \mathrm{ft}$. (only $100 \mathrm{ft}$. above south shore of Lake Ontario). Medina sandstone (Siluric). 
4. Upper Mississippi Valley section. Dip gently southeast. Crystallines; St. Croix (Potsdam) sandstone with Dikellocephalus $600 \mathrm{ft}$. Mag. nesian limestone (Beekmantown) $200 \mathrm{ft}$. St. Peter sandstone $150 \mathrm{ft}$. Stones River (Upper Chazy) 40 ft. Black River $50 \mathrm{ft}$. Galena limestone with Re. ceptaculites $200 \mathrm{ft}$. forming cliffs; hiatus; Ma. quoketa (Upper Richmond) 50 ft.; Niagara (Siluric).

5. Rocky Mountains section. Dipping about 30 degrees east. Granite; Basal sandstone (Potsdam) $30 \mathrm{ft}$ - - Beekmantown limestone 200 ft.; hiatus; Lower Trenton limestones $300 \mathrm{ft}$; hiatus; Upper Richmond limestone $100 \mathrm{ft}$.; hiatus; Mississippic limestones.

6. Appalachian sections. Beds dipping at angles of 45 degrees to 90 degrees-sandstones common. ly form sharp ridges. Shales and limestones form valleys.

6a. Central Pennsylvania. An anticline; beds on western limb vertical, on eastern dipping 45 degrees $E$. In center Upper Kittatinny limestone (Upper Cambric); Beekmantown limestone $2500 \mathrm{ft}$.; Chazy limestone $2500 \mathrm{ft}$.; Black River $100 \mathrm{ft}$; Trenton limestone $600 \mathrm{ft}$.; Utica shale $650 \mathrm{ft}$.; Frankfort and Lorraine $350 \mathrm{ft}$.; Bald Eagle Conglomerate (Lorraine or Early Richmond) forming Bald Eagle Mountain on west and Nittany Mountain on east $350 \mathrm{ft}$. Juniata, red sandstone (Richmond) $500 \mathrm{ft}$. Tuscarora sandstone-Medina-Siluric (forming ridge) $500 \mathrm{ft}$ - - Nittany Mountain is a syncline, with highest beds in center Juniata red beds. 
6b. Eastern Tennessee. Beds form monocline dipping about 45 degrees to the $\mathbf{S}$. E. crest of Clinch Mountain is formed by sandstone of that name. Knox dolomyte (Upper Cambric) $3500 \mathrm{tt}$. - forms broad valley. Chickamauga limestone$1700 \mathrm{ft}$. (Chazy); Sevier shale $600 \mathrm{ft}$. (Trenton); Bays Red sandstone $325 \mathrm{ft}$. (Richmond); Clinch sandstone $200 \mathrm{ft}$. (Medina), Rockwood formation $650 \mathrm{ft}$. (Niagara); hiatus; Hancock limestone 275 ft. (Helderberg); hiatus Black shaleDevonic to Missippic_-valley formation.

LABORATORY WORK WITH ORDOVICIC FOSSILS

$$
\text { (Trays B. 11-20.) }
$$

1. Ophileta-Beekmantown. Note numerous whorls, coiled nearly in a plane; gradual enlargement of coil, flat under and keeled upper side.

2. Maclurea-Chazy. Flat spire showing all coils-left-handed coiling, rapid enlargement, triangular section of whorl.

3. Phytopsis-Lowville. A series of tube-like or rod-like structures embedded in fine lime mud -as grass stems might be buried in mud accumulating around them. Section shown in all directions.

4. Columnaria-Black River. Compound, of slender prismatic tubes striated exteriorly, divided by crossplates or tabulae interiorly.

5. Prasopora-Trenton. Note form; wrinkled epitheca of flat base, finely prismatic tubes seen in section. 
6. Orthoceras-Trenton. Slender subcylindrical form gradually tapering, divided by concave septa. On surface of septum, note connect. ing tube or siphuncle.

7. Asaphus-Trenton. Similarity of head and pygidium, the former distinguished by large eyes; body (thorax) of a number of rings.

8. Trinucleus-Trenton. Head with three rounded lobes, the middle one largest. Outer rim ornate, with rows of pits. Lateral spines longseldom preserved.

9. Receptaculites-Galena. Form watchglass-shaped; like the bottom of a beaker-like or jar-like structure; walls composed of rods with crossbars at both ends, of saw-horse type. Arrangement such as to give external pattern resembling markings on machine-turned watch case.

10. Diplograptus-Utica. Slender, shiny black mark on surface of shale. Note toothed margins, formed by compressed cups or thecae.

11. Triarthrus-Utica. Head with square glabella, marked by backward converging furrows. Body (thorax) of many rings.

12. Rafinesquina-Cincinnati group. Concavo-convex, two valves almost in conjunction with little space between. Straight hinge-line, narrow hinge area, surface with alternating radiating striae.

13. Platystrophia-Cincinnati group. Coarsely plicate, long straight hinge line and areas on both valves. Median depression (sinus) on one, elevation (fold) on other valve, both plicate. 
14. Rhynchotrema-Cincinnati group. Like preceding but without straight hinge line and area.

15. Dalmanella_Cincinnati group. Hinge line short, area comparatively small, form nearly round. One valve convex the other flat or with median depression.

16. Plectambonites-Cincinnati group. Like No. 12 but smaller and proportionally wider and more convex.

17. Monticulipora-Cincinnati group. Of fine prismatic tubes, like No. 5 , but different in form; surface aperture of tubes polygonal.

18. Calymmene-Cincinnati group. Head with strongly divided median part (glabella), eyes and outline also distinctive.

\section{THE SILURIC SYSTEM.}

Named by Murchison from old English tribe of Silures. Restricted in America chiefly to central United States and northward. Mainly limestones and calcareous shales, with marine fossils in lower and upper part, and shales, red sandstones, conglomerates, salt and gypsum beds in the middle.

Standard Series.

Subdivision .......... Fossils.

Upper or Monroan.

Manlius limestone.......Tentaculites.

Rondout water-lime.....

Cobleskill limestone....... Halysites.

405 Bertie water-lime....... Eurypterus.

Lower Monroe beds....... 
Middle or Salinan.

Salina shales, gypsum and salt.

Lower or Niagaran.

Guelph dolomyte........

Lockport Limestone..... Halysites.

Rochester shale......... Caryocrinus.

Clinton Limestone and shale Pentamerus.

Medina sandstone........Arthrophycus.

\section{CHARACTERISTIC SECTIONS.}

1. Niagara Section: From Lake Ontario to Buffalo. Continuation of Ordovicic section, No. 3. Beds nearly horizontal. Most of series exposed in Niagara escarpment (200 ft. high) at Lewiston. Queenston red shales (Ordovicic) mostly under Lake Ontario,-about $60 \mathrm{ft}$. shown. Medina sandstone $125 \mathrm{ft}$.; Clinton group $40 \mathrm{ft}$.; Rochester shale $75 \mathrm{ft}$. (forms Cave of Winds with Clinton limestone as floor). Lockport and Guelph dolomite $200 \mathrm{ft}$. (the Falls over lower $80 \mathrm{ft}$.; rapids $50 \mathrm{ft}$. higher). Salina shales and gypsum $350 \mathrm{ft}$. Bertic water-lime $60 \mathrm{ft}$. Cobleskill $7 \mathrm{ft}$; hiatus; disconformity; Onondaga (Devonic).

2. Rosendale Section: Beds inclined 30 degrees west. Rest unconformably upon folded Hud. son River shale. Shawangunk conglomerate 200 ft. Longwood shale, etc., $40 \mathrm{ft}$. Rosendale waterlime $20 \mathrm{ft}$. Cobleskill limestone $15 \mathrm{ft}$. Rondout water-lime $20 \mathrm{ft}$. Manlius limestone $50 \mathrm{ft}$. Coeymans (Devonic).

3. Appalachian Sections: Clinch Mountain. Dip $45^{\circ}$ to S.E. upper part of Ordovicic section No. 6b. Western part of mountain formed by out crops of Ordovicic strata to Bays sandstone. 
Clinch sandstone $200 \mathrm{ft}$. (Medina) forms crest of mountain. Rockwood sandstones, shales and iron ores $650 \mathrm{ft}$. (Niagaran). Hiatus cutting out Middle and Upper Siluric; Hancock limestone (Dev. onic) or Black shale follows.

4. Central New York Section: Continuation of Ordovicic section No. 2. Dip gently south. Resting disconformably on Frankfort shale (Ordovicic). Oneida conglomerate $40 \mathrm{ft}$. (cliff former), Clinton-Niagara shale and sandstones $250 \mathrm{ft}$. Salina shales and gypsum $1000 \mathrm{ft}$. Bertie water lime $50 \mathrm{ft}$.; Cobleskill $10 \mathrm{ft}$.; Rondout water lime $20 \mathrm{ft}$.; Manlius limestone $50 \mathrm{ft}$.; Coeymans $5 \mathrm{ft}$. (Lower Devonic).

\section{LABORATORY WORK WITH SILURIC FOSSILS.} (Trays C. 1-10.)

1. Lingula, Medina. Note pointed form; shell symmetrical; horny character.

1a. Arthrophycus, Medina. Crossing of ridges. Note peculiar ornamentation of same. Occurs as molds on underside of rock corresponding to impression in mud beneath.

2. Anaplotheca, Clinton. Limestone mass compears as coaly streak on shale. Note arrangement

3. Pentamerus, Clinton. Large smooth symmetrical shells. Valves nearly equal, often only one shown.

4. Monograptus, Clinton. Compressed, appears as coaly streak on shale. Note arrangment and form of serrations (compressed hydrothecae).

5. Clinton iron ore. Note color, softness, etc. 
6. Fucoid, Clinton. Impression on shale or sandstone. Note branching and general outline.

7. Rochester shale, typical calcareous shale with Bryozoa.

8. Caryocrinus, Rochester. Nut-like form. Note point where stem was attached; also bases of arms. Trace outlines of plates of calyx, and ornamentation on same.

9. Calymmene, Niagaran limestones and dolomites. Often fragmentary. Head with median lobe or glabella strongly and peculiarly notched, this being character by which genus is recognized. Note form of cheeks, eyes, character of body lobes and form of pygidium, if present.

10. Halysites, Chain coral, Lockport, also Cobleskill. Compressed tubes oval in section unite by narrow sides, form irregular links.

11. Orthoceras annulare. Lockport, etc. Compare with Ordovicic Orthoceras. Note elevated rings with fine wrinkled lines between. Edges of concave septa do not correspond to rings.

12. Shawangunk Conglomerate. Quartz peb. bles rounded. Note general absence of other minerals than quartz. In character often like Bald Eagle or Tuscarora-Clinch, or Oneida.

13. Longwood shale. Typical red shale, in all essentials like Juniata, Bays or Queenston shale. Indications; semiarid climate during formation.

13a. Eurypterus, Bertie. Note head with eyes; body of numerous rings; tail-spine; appendages or paddle legs and walking legs. 
14. Tentaculites, Manlius, or Tentaculite limestone. Slender, tapering tubes strongly ringed.

15. Leperditia, Manlius. Bean-like, two valves with straight hinge-line, eye tubercle.

\section{THE DEVONIC SYSTEM.}

(Laboratory trays C. 11-20; D. 1-10 in part).

Name from Devonshire in Southwestern England, where marine formations of this age were first studied by Murchison and Sedgwick. Equivalent to Old Red System of Scotland.

Types of Sedimentation. (1) The open marine type consists of sandy beds and shales with pelecypods in Eastern North America, becoming calcareous shales with brachiopods further west, and coral reef limestone in Central and Western United States.

(2) Black shale type (Ohio type), probably in large part a delta deposit, like that of the Mississippi. Contains much fossil wood, but few animals. Also large spherical concretions.

(3) Continental type,-both gray and red. Characteristic of eastern United States and Canada. Oneonta and Catskill red sandstones, Gaspé sandstones, with plants, fresh water mussels and peculiar fish. Old Red sandstone of Scotland of this type-sometimes red sandstone or coarse conglomerate or fine grained flag stone (Caithness).

Distribution. Lower Devonic beds are found chiefly in eastern and southern United States, and in Rhine Valley region of Europe. Middle Devonic widespread in North America, often coral reefs. An eastern and a western type. Upper Devonic, 
American or Ithaca type, foreign or Naples type, the latter most widely distributed.

Standard Series.

Subdivisions

Fossils

Upper Devonic.

Chemung (or Catskill)-Spirifer disjunctus, (fish, plants.)

Portage beds.

Naples phase-Goniatites, Spirifer glabra.

Ithaca phase-Brachiopods.

Oneonta phase-Plants, Unios.

Genesee shales-Plants, Styliolina. Tully limestone-Rhynchonella, (Hypothyris) cuboides.

Middle Devonic:

Hamilton group-Spirifer mucronatus, corals, etc.

Marcellus black shales-Pelecypods, Styliolina.

Onodaga limestone-Corals (Favosites Zaphrentis etc.).

Schoharie and Esopus grits.

Lower Devonic :

Oriskany sandstone-Spirifer arenosus Rensselaeria.

Helderbergian beds-

Port Ewen-Leptaena.

Becraft-Gypidula pseudogaleata.

New Scotland-Spirifer macropleura.

Coeymans-Gypidula galeata. 


\section{CHARACTERISTIC SECTIONS.}

1. Helderberg Section. (Continuation of Siluric section, No. 2.) Beds gradually becoming horizontal, at first inclined $30^{\circ}$ west. Coeymans limestone $50 \mathrm{ft}$; New Scotland shaly beds $75 \mathrm{ft}$.; Becraft limestone $30 \mathrm{ft}$.; Port Ewen shaly beds $150 \mathrm{ft}$; Oriskany sandstone, etc. $60 \mathrm{ft}$.; EsopusSchoharie shales $350 \mathrm{ft}$; Onondaga $75 \mathrm{ft}$. (forms cliffs); Marcellus-Hamilton shales $600 \mathrm{ft}$.; Upper Hamilton sandstones $500 \mathrm{ft}$. (Lower flag-stones); Oneonta sandstones (Upper flag-stones) $3000 \mathrm{ft}$.; Catskill red sandstone and conglomerate $1700 \mathrm{ft}$.

2. Central New York Section. Continuation of Siluric section No. 4, from south of Utica in zigzag line to Elmira, passing through Clinton (site of Hamilton College); Oriskany battlefield; Hamilton (site of Colgate University); Tully; Ithaca (Cornell University) to Chemung River, near Elmira (State Reformatory).

Resting conformably on Manlius: Coeymans $\mathbf{5}$ ft.; erosion surface, hiatus; Oriskany sandstone 20 ft.; hiatus. Onondaga limestone $100 \mathrm{ft}$. ; Marcellus shale $180 \mathrm{ft}$.; Hamilton shales $1200 \mathrm{ft}$. ; Tully limestone $50 \mathrm{ft}$.; Genesee shale $100 \mathrm{ft}$.; Lower Portage sandstone (Naples fauna) $250 \mathrm{ft}$.; Ithaca shales $450 \mathrm{ft}$.; Upper Portage (Naples) shales and sandstones $600 \mathrm{ft}$.; Chemung sandstones and shales $1200 \mathrm{ft}$; Catskill shales $1250 \mathrm{ft}$; Olean (Carbonic) conglomerate at State line.

3. Western New York Section. Continuation of Siluric section 1 from Buffalo along Lake Erie to Dunkirk, then south to Pennsylvania line at Olean and Bradford. Beds nearly horizontal. At Buffalo resting disconformably on Cobleskill (eroded): Oriskany-streak; Onondaga limestone 
$200 \mathrm{ft}$.; Marcellus shales $200 \mathrm{ft}$.; Hamilton shales $200 \mathrm{ft}$.; Tully and Genesee very thin, Portage shales and sandstones $1300 \mathrm{ft}$.; Chemung shales and sandstones $1500 \mathrm{ft}$.; Cattaraugus shales and con. glomerates. (transition beds) 300 ft. hiatus;0swayo shales (Pocono) $250 \mathrm{ft}$. hiatus; Shenango shales (Mauch Chunk) $80 \mathrm{ft}$; hiatus; Olean con. glomerate (Carbonic).

4. Ideal Section of Middle Devonic. Hamilton formation from the Hudson to Lake Michigan. Beds originally horizontal. Sandstone and con. glomerates of terrestrial origin with plant remains in east. Merge westward into marine sandstones with mollusks, in western New York become calcareous shales with brachiopods and thin limestone beds and gradually limestone becomes more prominent until on Lake Michigan all is limestone.

5. Ideal Section of Upper Devonic, (Portage formation, ) in New York, showing faunas. On the east Continental Oneonta, plants and Unios, then shales with Ithaca fauna then shales and sand. stones with Naples fauna west of Central New York. In Central New York inter-fingering of two types. Followed by invasion of Chemung fauna from west and Catskill Continental sedimentation from east, the latter gradually overlapping the former.

LABORATORY WORK WITH DEVONIC FOSSILS. (Trays C. $11-20$; D. $1-10$ in part).

1. Gypidula galeata, Coeymans. Shell with sym. metrical valves, larger one strongly over-arching, 
plicate; smaller one (often not visible or absent), much flatter.

2. Spirifer macropleura, New Scotland. Large with few coarse plications. Also fine striations when shell is preserved.

3. Gypidula pseudogaleata. Becraft. Like (i) but smooth.

4. Leptaena rhomboidalis. Helderbergian, etc. Straight hinge-line, concentric wrinkles, abrupt bending down in front.

5. Spirifer arenosus, Oriskany. Large with regular plications which cover median depression (sinus) and elevation (fold).

6. Rensselaeria, Oriskany. Symmetrical valves nearly equal, elongate, with numerous regular striations.

7. Favosites, Onondaga-prismatic columns, showing mural pores.

8. Favosites. Same as No. 7, with tubes broken lengthwise showing horizontal plates or tabulae.

9. Favosites, Hamilton. Small, entire heads showing surface opening of tubes.

10. Acervularia, Western Hamilton. Compound with prismatic tubes, center of each strongly depressed; well marked septa.

11. Diplophyllum, Western Hamilton. Cylindrical tubes well developed; septa and tabulae well marked.

12. Pleurodictyum, Hamilton, Small heads of large and small tubes. 
13. Zaphrentis, Onondaga. Conical with somewhat bi-laterally arranged septa and deep septal groove or fossula.

14. Streptelasma, Hamilton, With radially arranged septa-otherwise much like preceding.

15. Heliophyllum, Hamilton, Large, coarsely wrinkled, numerous septa with cross-bars or carinae.

16. Cystiphyllum, Hamilton, Like preceding but without septa. A cystose structure in their place.

17. Spirifer mucronatus, Hamilton. Transversely elongated, plicated on either side of fold and sinus; narrow hinge area.

18. Stropheodonta, Hamilton. Concavo-con. vex shell, surface striated; hinge line with fine vertical teeth.

19. Atrypa, Hamilton. Robust, one valve, much deeper. Surface striate; no area.

20. Athyris; Hamilton. Smooth, nearly circular, valves nearly equal, very convex.

(Trays D. 1.10 in part).

1. Spirifer laevis. Portage; large, smooth with shallow median depression.

2. Goniatites, Portage. Generally strongly compressed. Coiled in plane, with angular septal margins.

3. Spirifer disjunctus, Chemung. Elongate, with many plications, extending over fold and sinus; internal mold deeply cleft or disjointed. 
4. Black shale. Representative of Marcellus, Genesee and Portage, black shales.

5. Red sandstone. Representative of Catskill and Old Red of Europe.

\section{MISSISSIPPIC, CARBONIC AND PERMIC SYSTEMS.}

$$
\text { (Trays D. } 1.10 \text { in part). }
$$

These comprise the old Carboniferous system, so named from the presence of coal for which it is the lowest horizon. Chief coal deposits found in the Carbonic (also called Pennsylvanic). Mississippic, named from Mississippi Valley where it is well developed, Permic named from district of Perm in Russia.

\section{Standard Series.}

Permic (German divisions).

Zechstein.

Rothliegende.

(Eastern American).

Dunkard or Upper Barren.

Carbonic: (Eastern North America).

Monongahela - or upper productive.

Conemaugh-or lower barren.

Alleghany-or lower productive.

Kanawha.

Pottsville (Millstone grit).

Mississippic: (Miss. Valley).

Chester,

St. Louis, 


\section{Waverlyan.}

Warsaw,

Keokuk,

Burlington,

Kinderhook.

In the Permic of North Europe great salt deposits (Stassfurt region); in Southern hemisphere evidence of glaciation abounds (S. Africa, India, Australia, South America).

Dwyka conglomerate of South Africa, typical ex ample of ancient boulder clay (tillite).

In North America as well as Europe the Mississippic deposits are mostly marine except in Appala. chian region, where they are continental. Car. bonic deposits of Continental origin in part, contain coal beds, the lowest productive beds being in the Pottsville, e.g. Pocahontas coal, Quinnimont coal, etc. Other important coals in Kanawha of W. Virginia. The Alleghany contains the Clarion, Kittanning and Freeport coals. The Monongahela, the Pittsburg coal at the base and the Waynesburg at the top. Conemaugh and Dunkard contain only thin, mostly unimportant coals.

\section{Characteristic Sections.}

1. Appalachian section. Schuylkill River. A series of folds. Section begins in Blue Ridge with Shawangunk conglomerate resting unconformably against Hudson River shales. Shawangunk conglomerate $30 \mathrm{ft}$.; Longwood red shale $1700 \mathrm{ft}$.; Lewis ton limestone (Monroe) $30 \mathrm{ft}$. (top of Siluric); hiatus; Oriskany sandstone $30 \mathrm{ft}$.; hiatus Hamilton and Portage $2000 \mathrm{ft}$. Catskill red sandstone 5000 $\mathrm{ft}$.; Pocono sandstone and conglomerate $1500 \mathrm{ft}$.; Mauch Chunk red shale $2000 \mathrm{ft}$; Pottsville con. glomerate $1250 \mathrm{ft}$.; Kanawha formation $1300 \mathrm{ft}$.; Aleghany $300+\mathrm{ft}$. 
Anticlines have vertical western limb, eastern limb about 45 degrees. First syncline halfway between Blue Ridge and Pottsville; Catskill in center; followed by anticline exposing top of Longwood; syncline at Pottsville carrying Kanawha and Alleghany; broad anticline exposing Portage in center; Small syncline with Catskill; east branch of Susquehanna. Beyond river axis of anticline exposing Longwood; syncline with Catskill, anticline in Portage, then beds follow to Pottsville in gradually dying out folds.

Shawangunk, Portage, Pocono and Pottsville form mountains.

2. Ohio-Western Pennsylvania Section. Beds nearly horizontal. Rest on Ohio Black shale. (Devonic), Waverly group, consisting of Bedford shale 85 feet; Berea grit $40 \mathrm{ft}$; Sunbury shale $15 \mathrm{ft}$.; Cuyahoga formation $300 \mathrm{ft}$; B Black Hand $40 \mathrm{ft}$. Logan sandstone $115 \mathrm{ft}$. (Kinderhook to Koekuk= Pocono); hiatus; Maxville limestone (Chester) 25 ft.; hiatus; Sharon conglomerate $100 \mathrm{ft}$. (Upper Pottsville); Mercer group (with Connoquenessing sandstone at base and Homewood at top age Kanawha) $200 \mathrm{ft}$.; Alleghany formation $350 \mathrm{ft}$.; Conemaugh $600 \mathrm{ft}$; Monongahela $375 \mathrm{ft}$; Dunkard or Washington $1200 \mathrm{ft}$.

3. Mississippi Valley Section: Beds nearly horizontal, resting unconformably on Devonic: Kinderhook shales and limestones $140 \mathrm{ft}$. Burlington $100 \mathrm{ft}$.; Warsaw $40 \mathrm{ft}$; ; hiatus; St. Louis 200 ft. ; Chester $200 \mathrm{ft}$; hiatus (cutting out Lower Carbonic Arkansan), followed by shales and limestones of Middle Carbonic or Des Moinian, which comprises in Kansas: Cherokee $450 \mathrm{ft}$. and Mar- 
maton $385 \mathrm{ft}$; then Upper Carbonic or Missourian comprising Pottawatomie $735 \mathrm{ft}$.; Douglas $190 \mathrm{ft}$.; Shawnee $507 \mathrm{ft}$. Succeeding this are Permic shales and limestones comprising Wabaunsee 300 ft.; Cottonwood $125 \mathrm{ft}$.; Chase $255 \mathrm{ft}$.; Sumner $350 \mathrm{ft}$; and the red Cimarron sandstones shales and gypsum $1400 \mathrm{ft}$.. Disconformity; Cretacic beds.

\section{IABORATORY WORK WITH MISSISSIPPIC, CAR - BONIC AND PERMIC FOSSILS.}

(Trays D. 1.10 in part).

6. Dizygocrinus. Burlington; sub-spherical form of regularly arranged series of smooth plates in lower part with scar of stem attachment, and ir. regular plates in upper part (tegmen) prolonged into central anal tube. Arm openings around mid. dle.

7. Macrocrinus, Burlington. Calyx pearshaped, top (tegem) sloping, arm bases about 14, anal tube (often broken away) long.

7a. Lithostrotion, St. Louis. Compound; tubes prismatic, septa well developed meet in center in pronounced columella.

7b. Melonites, St. Louis. Melon-shaped. Ambulacral and interambulacral areas each of numer. ous rows of small plates, the former with pores.

8. Pentremites. Chester. Bud-like form; note five petaloid ambulacral areas and flve openings on top-the largest opening includes anus. Mouth in centre.

9. Crinoid stem. Ordovicic to recent; Missis sippic. Composed of discs or joints more or less flexible. Surface of disks radially striate. Median canal. Form and ornamentation varies greatly. 
10. Fusulina. Carbonic limestone (marine). Elongate spindle-like form. In section note spiral coiling and successive chambers.

11. Productus. Carbonic limestone (marine), symmetrical when not compressed. Large valve strongly curved with incurved beak. Hinge line straight often spiny-surface with interrupted ridges and spine.

12a. Pecopteris, Carbonic concretion. Midrib with numerous closely set pinnules, joining it with straight base at nearly right angles.

12b. Neuropteris, Carbonic concretion; single large pinnule with indented base. Note forked veining.

12c. Calamites, Carbonic, stony cast-rarely with bark preserved. Note jointing and vertical striations.

12d. Sigillaria. Carbonic. Often with bark preserved but flattened. Vertical ridges with leaf scars between.

12e. Lepidodendron, Carbonic. Same as preceding, but leaf scars in diamond-shaped areas.

12f. Stigmaria. Carbonic. Root stock of preceding found in under-clay or sand, rootlets attached at circular scars..

12g. Cordaites, Carbonic. Strap-shaped leaf with parallel veining.

13. Mauch Chunk Red Shale. Mississippic. Similar to older red shales. 
14. Pottsville conglomerate.

(Millstone

Grit), with rounded quartz pebbles like Shawan. gunk, etc. Pocono often more sandy.

15. Coal shale (Roof shale). Carbonic. Showing plant impressions.

16. Carbonic sandstone, prevailing rock of Coal Measures.

\section{GENERAL PALAEOZOIC SECTIONS.}

1. Central Wisconsin, S.E. to Central Michigan. Strata dip gently S.E. On Precambric of Wisconsin: St. Croix (Potsdam) sandstone $600 \mathrm{ft}$.; Lower Magnesian limestone (Beekmantown) 200 ft.; St. Peter sandstone $150 \mathrm{ft}$.; Stones River, Black River, and Galena, $300 \mathrm{ft}$; hiatus; Maquo. keta $50 \mathrm{ft}$.; Niagarian limestone with iron ore at base $800 \mathrm{ft}$; hiatus; Monroe dolomytes (Upper Siluric) $500 \mathrm{ft}$; hiatus; Salina with salt and gyp. sum $1000 \mathrm{ft}$.; hiatus; Onondaga $150 \mathrm{ft}$.; Traverse group (Hamilton) $600 \mathrm{ft}$; Antrim Black shale $200 \mathrm{ft}$; hiatus; Waverly group $1000 \mathrm{ft}$. Coal Measures $700 \mathrm{ft}$.

Green Bay excavated in Maquoketa shale, cliff on southeast, of Niagarian limestone which dips un. der Lake Michigan. Islands in lake, partly Monroe, partly Onondaga. East shore of Lake Michigan, formed by Traverse limestone cliffs.

2. Rocky Mountain Section. Strata dip 30 degress east. On granite of Pike's Peak is basal Deadwood sandstone ("Potsdam", or Upper Cam. bric), $30 \mathrm{ft}$. Followed by Manitou limestone (Beekmantown) $200 \mathrm{ft}$; hiatus; Lower Freemont limestone (Trenton) $300 \mathrm{ft}$; hiatus; Upper Freemont limestone (Maquoketa) $100 \mathrm{ft}$. ; hiatus; Mill. sap limestone (Mississippic) $400 \mathrm{ft}$. ; Fountain red 
sandstones and shale (Carbonic) $2000 \mathrm{ft}$; fault bringing Upper Fountain beds vertically against the others; Chugwater red beds (Triassic).

\section{MESOZOIC SECTIONS. TRIASSIC SYSTEM.}

Original sub-division in Germany threefold.

3. Upper Trias or Keuper.

2. Middle Trias or Muschelkalk.

1. Lower Trias or Bunter sandstone.

1 and 3 continental deposits; 2 is marine. In Alps and India extensive limestone series represent whole Trias. In England only red sandstones, called New Red (in part Permic). Red sandstones with basalt flows and intrusions (Newark system) of Keuper age, in eastern North America from Nova Scotia to Pennsylvania; coal beds in place of basalt from Pennsylvania to Carolina. In Western U. S. east of Cordillerans, red and variegated sandstones form principal deposits, sometimes with extensive petrified forests, as in Arizona. On Pacific Coast (California, Nevada, Oregon, Idaho, Utah), marine limestone with Ceratites occur.

\section{JURASSIC SYSTEM.}

Named from occurrence in Jura Mountains, mainly limestones, some shales and sandstones. Upper division in southern Germany contains lithographic limestones.

Typical European Succession.

3. Upper or White Jura or Malm.

2. Middle or Brown Jura or Dogger.

1. Lower or Black Jura or Lias. 
In America marine limestones and shales only in Pacific States, with arm reaching to Black Hills. Represents only part of series. Along Front Range beds are of continental origin, with remains of huge reptiles (Dinosaurs, etc.) Eastern United States, mainly clays and sands.

\section{COMANCHIC SYSTEM.}

Named after Comanche tribe of Indians in South ern U. S. where system is best developed. Mostly limestones, some shales and sandstones.

Typical Succession.

4. Dakota sandstone-transition member.

3. Upper Comanchic or Washita.

2. Middle Comanchic or Fredericksburg.

1. Lower Comanchic or Trinity.

Most typically developed in Mexico, Texas, Oklahoma, North to Kansas. On Atlantic Coast mainly clays and sands. In Europe limestones, clays, etc. Greensands and clays in England.

\section{CRETACIC SYSTEM.}

Named from occurence of chalk (creta) in England and France. Chalk composed largely of foraminiferal shells. Flint concretions in layers. In Central United States mostly shales and limestones; on Atlantic Coast, clays, sands and greensands. On Pacific Coast mostly shales.

Characteristic American Succession.

Upper Cretacic or Laramian.

Middle Cretacic or Montanan.

Fox Hill series.

Pierre series. 
Lower Cretacic or Coloradoan.

Niobrara series.

Benton series.

Dakota Sandstone, transition series.

\section{CHARACTERISTIC SECTIONS.}

1. From the Black Forest southwest through the Swabian Alb to the foot of the Alps. Strata dip gently southwest, becoming steeper in Upper Swabia, where they form broad syncline and are turned up nearly vertically at the Alps where much faulting and thrusting occurred.

Begins at Rhine Graben, a fault valley bounded by step faults and occupied by Oligocenic, Pliocenic and Quaternary deposits. Black Forest of gneisses and intrusives, followed by Bunter sandstone, overlapping Rothliegende sandstone of Permic. Succeeded by Muschelkalk, and Keuper. Neckar Valley and Tubing on Muschelkalk; hills beyond of Keuper capped by Rhaetic and Lias limestones and Marls. Dogger-beds seen in face of Swabian Alb which is formed by great limestone beds of White Jura. This sinks to valley of Danube from which stream to the Alps is a broad syncline of Tertiary and Quaternary strata. In Alps, Tertiary is much faulted with steep dips and overthrusts by Cretacic limestones and then by Triassic and some Jurassic limestones, all strongly folded.

2. Across Central England, from Pre-Cambric area of Long Mynd in Shropshire to London. On crystallines rest Cambric dipping steeply east followed unconformably by Upper Ordovicic at a lower angle. Then with another slight unconformity and still gentler dip follow Siluric shales and limestones, the latter forming escarpment (Wen- 
lock edge). Followed by Ludlow or Upper Siluric and a part of Old Red sandstone into which it grades. Then with a disconformity follow Carbonic Coal Measures and some Permic red sand. stone, all dipping gently east. Then follows New Red Sandstone forming Worcester lowland; crossing the Severn, we find Lias clays, still in low coun. try. Crossing the Avon below Stratford, we ascend the Cotswold hills, a much dissected escarpment of Lower Oolites. Then we descend to valley at $0 x$ ford, formed of Middle and part of Upper Oolites (Dogger and part of Malm) which are here mostly clays. Hiatus, cutting out part of Upper Jura and Lower Comanchic. Green sand and Gault clay lie at foot of Chiltern Hills escarpment, capped by white chalk. Descending back of chalk slope we come to Eocenic clays and sands of London areadipping under the sea.

3 Rocky Mountains (Bighorn Mts.) Beds dipping $45^{\circ}$ east, later becoming horizontal. Rest on granite. Deadwood sandstone $1000 \mathrm{ft}$. (Cambric); Bighorn limestone, (Ordovicic) $100 \mathrm{ft}$; hiatus; Madison limestone $500 \mathrm{ft}$. (Mississippic) forms ridges. Carbonic and Permic limestone and sandstone $350 \mathrm{ft}$.; Chugwater red beds (Triassic) $1200 \mathrm{ft}$.; Sundance (Marine Jurassic) $450 \mathrm{ft}$. Morrison (Continental Jurassic) $250 \mathrm{ft}$.; Dakota s.s. $100 \mathrm{ft}$. Benton shales $1300 \mathrm{ft}$. Niobrara lime. stone $200 \mathrm{ft}$. Pierre shales $2000 \mathrm{ft}$. Fox Hills beds $300 \mathrm{ft}$.; Laramie beds with coal $3000 \mathrm{ft}$. ; Ter. tiary (non marine) $5000 \mathrm{ft}$.

4. New Jersey to Connecticut Valley, showing Newark system. Rest on old peneplain surface of schists and gneisses. West of Hudson, beds dip 15 or 20 degrees west. All red sandstones, with in. 
cluded sill of Palisade diabase near bottom and two sheets of basalt in upper part. Becomes very coarse towards border of crystallines. Fault at Hudson; brings shist to level of Cretacic peneplain. In Connecticut Valley beds dip east. Several faults traverse it. Lava sheets form ridges. Small area of down-faulted Newark 30 miles west of Connecti. cut Valley.

5. Atlantic Coastal Plain. Strata dipping gently east. Resting unconformably on Pre-Cambric and on folded Triassic. Potomac formation camprising: Patuxent clays $100 \mathrm{ft}$. Arundel clays $125 \mathrm{ft}$. (Jurassic); Patapsco $240 \mathrm{ft}$. (Comanchic); Raritan sand $400 \mathrm{ft}$. (Dakota, top of Comanchic); Hiatus. Ripleyan $500 \mathrm{ft}$. (Middle Cretacic). Jerseyan $175 \mathrm{ft}$. (Upper Cretacic); Shark River beds (Eocenic).

\section{LABORATORY WORK WITH TRIASSIC AND JURASSIC ROCKS AND FOSSILS.}

$$
\text { (Trays D. 11-20). }
$$

\section{TRIASSIC.}

1. Triassic Sandstone. Typical of Newark, of Triassic of Western America, of New Red Sandstone of England and of Bunter sandstone of Germany.

2. Fossil fish. Flattened on black shale, representing temporary water bodies.

2a. Footprint of Dinosaur. Impressions and mold of same from Newark sandstone.

3. Estheria. Fossil Branchiopod crustaceantwo-valved. Fresh water. 
4. Fossil Wood. Petrified forest of Arizona, entirely replaced by silica.

4a. Ceratites. Muschelkalk, Germany. Note coiling in single plane; heavy ribs; sutures of many forward bending saddles and backward bending lobes, the latter serrated.

4b. Encrinus liliiformis, Muschelkalk, Germany. Note regular arrangement of plates of calyx and arms; stem of alternating joints.

5. Trap Rock. Characteristic of Newark system. Nova Scotia to New Jersey.

\section{JURASSIC.}

6. Belemnites. Note ciger-shaped guard; radial structure where broken; deep conical hollow for insertion of actual shell or phragmocone (6a) (Western America).

7. Gryphaea incurva Lias. Very convex under valve, with incurved beak; upper valve small, operculum-like. Europe.

8. Ammonites (Amaltheus) margaritanus, Lias. Coiling in single plane, laterally compressed, whorls somewhat embracing; ornamented by ribs. Keel with rope-like ornamentation. Suture com. plex. Europe.

9. Pentacrinus stem, Lias. Joints pentagonal, highly ornate.

9a. Icthyosaurus, Lias. Fish lizard. Extinct marine reptile. Europe. 
10. Ammonites (Stephanoceras) humphries. ianus, Dogger. Note rounded whorls partly embracing - strong ornamentation on inner half of whorls. Europe.

11. Lithographic Stone. Malm, with floating crinoid, and dendritic markings. Solnhofen.

12. Fossil Fish. Malm. Lithographic limestone. Solnhofen.

12a. Limulus, or Horseshoe Crab, Malm; Lithographic limestone. Solnhofen.

12b. Fossil Dragon Fly. Malm. Lithographic limestone. Solnhofen.

\section{LABORATORY WORK WITH COMANCHIC AND CRETACIC ROCKS AND FOSSILS.}

\section{(Trays E. 1-10).}

1. Gryphaea corrugata (Comanchic). Elongate deep lower valve, with incurved beak, broad hinge area, single muscle scar; upper valves flat.

2. Leaf of Dicotyledonous plant. Cretacic, Dakota sandstone, form often outlined in precipitated iron oxide.

3. Exogyra costata Cretacic: Montanan. Lower deep valve as in Gryphaea, but beak twisted exteriorly on one side. Surface ribbed.

4. Inoceramus deformia. Niobrara. Large, coarse, shell thick, of prismatic columns. Surface with strong concentric wrinkles.

5. Inoceramus crispii. Cretacic: Montanan. Smaller than No. 4, elongate, shell thinner: concentric wrinkles marked. 
6. Gryphaea convexa. Ripleyan of Atlantic Coast. Compare with No. 1. beak smaller, less in. curved.

7. Ostraea. Laramie. Differs from Gryphaea in shallower valve, beak not incurved.

8. Ostrea falcata. Ripleyan. Small plicated, sickle-shaped valves.

9. Exogyra arietina. Small; lower valve strongly coiled, resembling some gastropods.

10. Bacculites, Montanan. Straight, compressed, septa with much folded margins.

11. Scaphites, Montanan. Coiled in single plane, last portion somewhat loosely coiled; shell with ribbed and in older specimens, noded exterior.

12. Terebratella. Shell with symmetrical, strongly plicated valves, straight but narrow hinge area.

13. Greensand. (Glauconite). Cretacic. Mostly formed as internal molds of foraminiferal shells. Wide spread in Cretacic.

14. Chalk. Composed largely of foraminiferal shells (see slide) characteristic of Upper Cretacic of Western Europe.

15. Flint Nodules. Occur in layers in chalk. Often accumulate around a sponge or other organ. ism as nucleus.

16. Laramie plant. Characteristic of coal swamps of Laramie time. 


\section{CENOZOIC (TERTIARY). SYSTEMS.}

The early division, made in 1828 , by Lyell, was into Eocene (dawn of recent, with $3 \frac{1}{2}$ per cent. of recent species of shells). Miocene (medial recent 17 per cent. recent species), and Pliocene (late recent, with 35 to $50 \%$ of recent species). These percentages are no longer relied upon. Oligiocene coined subsequently by Beyrich for part of Upper Eocene and Lower Miocene of North Germany.

Two types of sedimentation-the marine and the non-marine. In North America marine confined to Atlantic and Gulf coasts. In Europe, more widely spread, but generally in basins, Eocenic best developed in London, Hampshire and Paris Basins. Oligocenic in North Germany widespread but mostly under cover-in the Rhine Valley especially at Mainz and Cassel, etc. Miocenic especially in Vienna Basin, and in Western France, and Pliocenic especially in Italy. In America marine Oligocenic and Pliocenic are best developed on Gulf Coast.

\section{Characteristic Sections.}

1. Atlantic Coastal Plain. Dipping gently eastward, resting discomformably on Ripleyan Cretacic. Pamunkey sands and clays (marine Eocenic) 200 ft.; hiatus; Oligocenic wanting. Chesapeake sands and clays (marine Miocenic) $400 \mathrm{ft}$.; Lafayette (Pliocenic, non-marine) $50 \mathrm{ft}$.; Columbia gravels (Pleistocenic) $30 \mathrm{ft}$.

2. Gulf Coast. Dipping gently southward resting discomformably on Ripleyan Cretacic. Eocenic: Claytonian limestone, etc. $200 \mathrm{ft}$; Chickasawan sands and lignites, $900 \mathrm{ft}$; Buhrstone beds, 300 $\mathrm{ft}$; Claiborne formation $140 \mathrm{ft}$.; Jacksonian limestone, $150 \mathrm{ft}$. Oligocenic: Vicksburg limestone $200 \mathrm{ft}$. Chattahoochee beds, $70 \mathrm{ft}$. ; Chipola marls 
$50 \mathrm{ft}$. Miocenic: Chesapeakian, etc. $80 \mathrm{ft}$.; Pliocenic Caloosahatchie beds $50 \mathrm{ft}$. Pleistocenic, gravels and Loess $100 \mathrm{ft}$.

3.. Great Basin and Plains Sections. These are horizontal strata of terrestrial origin-mostly fluvial or eolian, and not always represented in the same locality. The succession from below up is: Eocenic $4600 \mathrm{ft}$. divided into: Puerco $500 \mathrm{ft}$.; Torrejon $300 \mathrm{ft}$. Wasatch $200 \mathrm{ft}$. Wind River 800 ft. Bridger $2000 \mathrm{ft}$. Uinta $800 \mathrm{ft}$. Oligocenic $1300 \mathrm{ft}$. Comprising only the White River $800 \mathrm{ft}$., and the Lower John Day about $500 \mathrm{ft}$. Miocenic, $1000 \mathrm{ft}$. + comprising the Upper John Day $500 \mathrm{ft}$. the Deep River $150 \mathrm{ft}$; the Loup Fork $400 \mathrm{ft}$. Pliocenic, comprising only the Blanco formation $150 \mathrm{ft}$. and Pleistocenic represented by the Sheridan beds $100 \mathrm{ft}$. thick.

LABORATORY WORK WITH CENOZOIC (TER. TIARY) AND PSYCHOZOIC (QUATERNARY) FOSSILS.

1. Turritella mortoni; Eocenic. Internal mold - note spiral coil.

1a. Turritella mortoni, shell; Eocenic, whorls with spiral ornamentation.

2. Terebratula, Eocenic. Unequal but bilater. ally symmetrical valves, large formamen of pedicle valve, surface smooth.

3. Nummulites, Eocenic. Note form; compare section in Trays A 1-10, Europe.

4. Cerithium. Eocenic, compare with Turritella. Note greater ornamentation and notch in lip. 
5. Lamna-Sharks tooth. Eocenic.

6. Lamna-vertebra-Eocenic; bi-concave.

7. Turritella, Miocenic, compare with 1 and la.

8. Crepidula, Miocenic. Spire small on one side. Broad shelf-like columella.

9. Arca, Miocenic. Note teeth and hinge area 10. Arca, Miocenic. Compare with 9.

11. Chama, Miocenic. Roughly coiled, lower valve, upper valve flat, two muscle scars, surface rough.

12. Glycimeris (Pectunculus), Miocenic. Nearly round symmetrical valves, note hinge teeth and area, compare with 9 ; Surface with plications.

13. Lucina, Miocenic, compare with 12.

14. Crassatellites, Miocenic. Elongate strong hinge teeth, peculiar form.

15. Pecten, Miocenic. Note form and size. Nearly symmetrical, strong ornamented plications.

16. Maretia, Oligocenic; form; disposition of ambulacral areas, mouth, anus, etc.

17. Cladophyllia, Pliocenic. Long cylindrical, septa in multiples of six.

18. Saxicava, Pleistocenic, elongate shell, rough exterior. 
$F B-08181-5 B$ 5-42 



\section{Date Due}

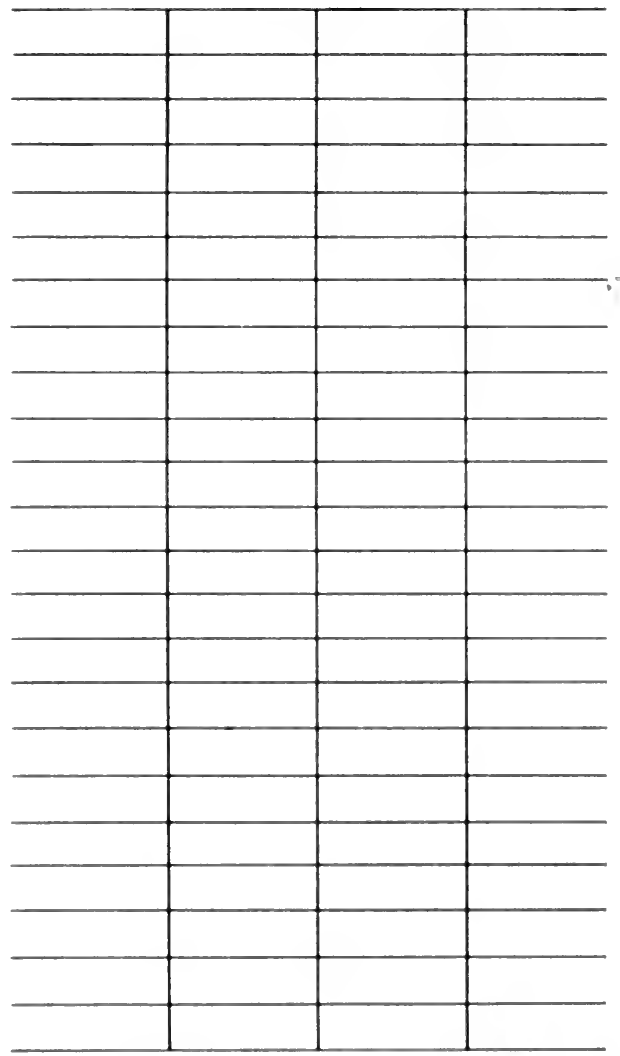

mintedimu.s. CAT No. 24161 
UC SOUTHERN REGIONAL LIBAARY FACLLITY 
